\title{
Noninvasive Ventilation Works in All Restrictive Diseases with Hypercapnia Whatever the Cause
}

\author{
D. Köhler \\ Beatmungs- und Schlafmedizin, Zentrum für Pneumologie, Krankenhaus Kloster Grafschaft, \\ Schmallenberg-Grafschaft, Deutschland
}

Home mechanical ventilation with nasal or oronasal interfaces has come of age. There has been a tremendous increase in this treatment in the last 10 years. Especially in thoraco-restrictive lung disease this treatment has been proven to be very successful. It improves hypercapnia and hypoxemia during the day [1-3] increases exercise capacity by more than $200 \%$ [2] and prolongs life expectancy [4-7]. The case report from Muñoz et al. [8] in this issue of Respiration dealing with asbestos-related lung fibrosis gives another example of this effectiveness.

How does noninvasive ventilation (NIV) work? Muñoz et al. [8] correctly mentioned the term 'ventilatory insufficiency'. An obligatory clinical sign of ventilatory insufficiency is hypercapnia caused by hypoventilation. This hypoventilation is a wise strategy $[9,10]$ of the body to avoid an overload of the respiratory pump. The following hypoxemia must be accepted, but the organism has some coping strategies to avoid ATP shortage in the periphery such as polyglobulia [11], decrease in 2,3diphosphoglycerate in the erythrocytes [12] and expression of enzymes of the cytochromoxidase being adapted to the lower oxygen partial pressure range [13, 14].

NIV unloads the respiratory pump, the longer the duration, the better. During this unloading period the replacement of muscle glycogen may be an important reason for the success of the ventilation. Glycogen acts as an

\begin{tabular}{ll}
\hline KARGER & ( 2001 S. Karger AG, Basel \\
Fon + 4161306 12 34 & \\
$\begin{array}{l}\text { E-Mail karger@karger.ch } \\
\text { www.karger.com }\end{array}$ & $\begin{array}{l}\text { Accessible online at: } \\
\text { www.karger.com/journals/res }\end{array}$
\end{tabular}

energy supply in skeletal muscles for a period of $12-36 \mathrm{~h}$ [15-17]. The unloading effect of NIV is possibly better realized in the 'controlled' rather than the 'assisted' mode of the ventilator [18]. NIV treatment in the present case report achieves close to normal $\mathrm{PCO}_{2}$ levels despite severe hypercapnia before starting. The controlled mode of the ventilator was used. Compared to the assisted mode the controlled mode in conscious patients is sometimes difficult to apply. This may be the reason for the rare use of this technique in NIV. The presented case should encourage trials that further investigate the most adequate treatment regime with NIV for our patients.

Prof. Dr. D. Köhler

Beatmungs- und Schlafmedizin, Zentrum für Pneumologie

Krankenhaus Kloster Grafschaft

D-57392 Schmallenberg-Grafschaft (Germany)

Fax +4929727912526 


\section{References}

1 Jones SE, Packham S, Hebden M, Smith AP: Domiciliary nocturnal intermittent positive pressure ventilation in patients with respiratory failure due to severe COPD: Long-term follow-up and effect on survival. Thorax 1998;53: 495-498.

2 Schönhofer B, Ardes P, Geibel M, Köhler D, Jones PW: Evaluation of a movement detector to measure daily activity in patients with chronic lung disease. Eur Respir J 1997;10: 2814-2819.

3 Schönhofer B, Geibel M, Sonneborn M, Haidl P, Köhler D: Daytime mechanical ventilation in chronic respiratory insufficiency. Eur Respir J 1997; 10:2840-2846.

4 Annane D, Chevrolet JC, Chevret S, Raphael JC: Nocturnal mechanical ventilation for chronic hypoventilation in patients with neuromuscular and chest wall disorders. Cochrane Database Syst Rev 2000;2:CD001941.

5 Leger P, Bedicam JM, Cornette A, ReybetDegat O, Langevin B, Polu JM, Jeannin L, Robert D: Nasal intermittent positive pressure ventilation. Long-term follow-up in patients with severe chronic respiratory insufficiency. Chest 1994;105:100-105.
6 Simonds AK, Elliott MW: Outcome of domiciliary nasal intermittent positive pressure ventilation in restrictive and obstructive disorders. Thorax 1995;50:604-609.

7 Simonds AK, Muntoni F, Heather S, Feidling $\mathrm{S}$ : Impact of nasal ventilation on survival in hypercapnic Duchenne muscular dystrophy. Thorax 1998;53:949-952.

8 Muñoz X, et al: Ventilatory insufficiency due to asbestos-related diffuse pleural fibrosis successfully treated with non-invasive home mechanical ventilation. Respiration 2001;68:533536.

9 Begin P, Grassino A: Inspiratory muscle dysfunction and chronic hypercapnia in chronic obstructive pulmonary disease. Am Rev Respir Dis 1991;143:905-912.

10 Snyder AC: Overtraining and glycogen depletion hypothesis. Med Sci Sports Exerc 1998;30: 1146-1150.

11 Köhler D, Schönhofer B: How important is the differentiation between apnea and hypopnea? Respiration 1997;64(suppl 1):15-21.

12 Palange P, Carlone S, Serra P, Mannix ET, Manfredi F, Farber MO: Pharmacologic elevation of blood inorganic phosphate in hypoxemic patients with COPD. Chest 1991;100: 147-150.
13 Jansson E, Sylven C, Arvidsson I, Eriksson E: Increase in myoglobin content and decrease in oxidative enzyme activities by leg muscle immobilization in man. Acta Physiol Scand 1988; 132:515-517.

14 Terrados N, Jansson E, Sylven C, Kaijser L: Is hypoxia a stimulus for synthesis of oxidative enzymes and myoglobin? J Appl Physiol 1990; 68:2369-2372.

15 Ferguson GT, Irvin CG, Cherniack RM: Relationship of diaphragm glycogen, lactate, and function to respiratory failure. Am Rev Respir Dis 1990;141:926-932.

16 MacDougall JD, Ward GR, Sutton JR: Muscle glycogen repletion after high-intensity intermittent exercise. J Appl Physiol 1977;42:129_ 132.

17 Rodgers CD: Fuel metabolism during exercise: The role of the glucose-fatty acid cycle in mediating carbohydrate and fat metabolism. Can J Appl Physiol 1998;23:528-533.

18 Rasche K, Laier-Groeneveld G, Weyland W, Braun U, Hüttemann U, Criee CP: Sauerstoffverbrauch der Atemmuskulatur unter kontrollierter bzw. assistierter Beatmung bei Patienten mit chronischer Ateminsuffizienz. Med Klin 1994;89:43-46. 